\title{
Effect of store atmospherics on customer buying behaviour
}

Received: 13.08.2015; Revised: 03.11.2015; Accepted: 12.11.2015

See end of the paper for authors' affiliations

\section{RAMANDEEP BAWA}

Department of Anthropology,

Punjab University, CHANDIGARH

(U.T.) INDIA

Email : raman_rapy@yahoo.co.in
- ABSTRACT : The present study investigated the design of an environment via visual communications, lighting, colours, music and scent to stimulate customers' perceptual and emotional response and ultimately affect their purchase behaviour. For the present research work purposive sampling, Interview schedule and convenient sampling methods were used to carry out the research work. The sample size consisted of 140 research scholars from faculty of arts and Sciences of Punjab University, Chandigarh. The major findings showed that store atmospherics bring a psychological feeling in the mind of customers who enters the store. The sight, sound, smell, displays, colour, mannequins in a retail store all contribute to customer perceptions. Almost all the customers get motivated by elegant store fronts, fantasy windows, mannequins, posters which influence their buying behaviour. It was further found out that store atmospherics emphasize on combining visual and other sensory elements that capture customer attention who enter the retail stores, awaken their senses through music, scent, and provides the customer a wonderful buying experience. Different types of displays attract, compel and persuade customer's senses, striking the right chord in him and arising in them an emotion to possess the product in display, thus persuade them to make an impulse purchase.

- KEY WORDS: Store atmospherics, Windows, Displays, Customer senses and Mannequins

- HOW TO CITE THIS PAPER : Bawa, Ramandeep, Sinha, A.K. and Kant, Rita (2015). Effect of store atmospherics on customer buying behaviour. Asian J. Home Sci., 10 (2) : 386-394. 